\title{
Harmonized Rating Land Property in Terms of Its Geometric Configuration
}

\section{Introduction}

The market value of property is the most probable price obtainable while complying conditions definition contained in article 151 paragraph 1 law on 21 August 1997 y. on real estate management [8]. Size estimation value is such a resultant force of influence on price-setting factors. Both market characteristics and the power of their impact on transaction prices, observed on right-factly and local real estate market, should be determined autonomously on occasion estimating the specific valuation subject. In this context, attention should be paid to the specific good (object) which is undeveloped land properties. It describes a series characteristics market, discretionary, because received by a real estate appraiser. They represent a set of price determinants, which arbitrarily, but with a high probability, you may include geometric configuration of property. It also notes Stefan Mielewczyk about agricultural plot writing: incorrect shape expanse of field grassland is the cause of increased cost associated with growing expanse this field, thus reducing his income [6]. The significance geometry of agricultural properties was also noted and included in draft "KSWS Wycena Nieruchomości Rolnych" (Ang. KSWS Agricultural Property Valuation), recommending a description and assessment state to take into account among others real estate shape [5]. It seems to be an obvious observation both Milczewski and Komisja Standardów Zawodowych (Ang. Professional Standards Commission) that the value of real estate, agricultural, in this case, depends largely on its shape. After all, this affects the economy of agro-technical works carried out on it, which on also expected net income.

In the case of estimating the value of undeveloped land, but designed for buildings, priority its geometric configuration is undisputed. Determines primarily because investment opportunities and widely understood spatial order, not only within its borders but also in its immediate vicinity. This, like fortresses Tomasz

* AGH University of Science and Technology, Faculty of Mining Surveying and Environmental Engineering, Department of Geomatics, Krakow, Poland 
Podciborski and Jacek Kil, is a factor in creating a demand for real estate, lifting attractiveness as well as their material value [7].

In this paper authors propose a methodology for assessing the shape of property, which eliminates the pejorative influence of discretionary assessment appraisers. Contribution to take this issue was a statement by the head of the analysis department RealExperts.pl Tomasz Kotrasiński at Ogólnopolska Lista Dyskusyjna Rzeczoznawców Majątkowych (ang. National Valuers Mailing List) on 04.11.2009 y., in which he proposed that the shape of plot assessed based on its surface area to square of circuit [3]. In development of this proposal was developed algorithm to rating geometry of plot land, applying later to estimate the market value of a representative object valuation.

\section{Algorithm Description}

The author's methodology to autonomous rating geometry plot land is based on knowledge of plane coordinates points kinks its borders. It should be emphasized, that they need not be in applicable coordinate system "2000". Suffice because the coordinates in an orthogonal system of freely chosen local start and metric intervals axis OX and OY. The goal of full automation procedures reduced the human factor to draw up a text batch file with coordinates points collapse of plot or coherent set of parcels making up estimation object. Their complete characterization was based on a block diagram drawn algorithm leading to strict and independent determinants of geometric parameterization land on the basis of two factors: compactness and elongation (Fig. 1).

The first stage is determined the minimum bounding box for land parcel. Then lengths of sides and surface area rectangle were calculated. It is also determined surface of this land parcel. Of the area should be set as:

$$
\begin{gathered}
P=\frac{1}{2} \cdot \sum_{i=1}^{n} X_{i} \cdot\left(Y_{i+1}-Y_{i-1}\right) \\
P=-\frac{1}{2} \cdot \sum_{i=1}^{n} Y_{i} \cdot\left(X_{i+1}-X_{i-1}\right)
\end{gathered}
$$

Equations (1) and (2) should be used together, as they represent mutual control calculations [4]. Positive verification of areas allows for the determination:

- elongation factor $(F e)$, as ratio shorter to longer side of minimum bounding box,

- compactness factor $(F i)$, as ratio surface area of land property to area of minimum bounding box. 


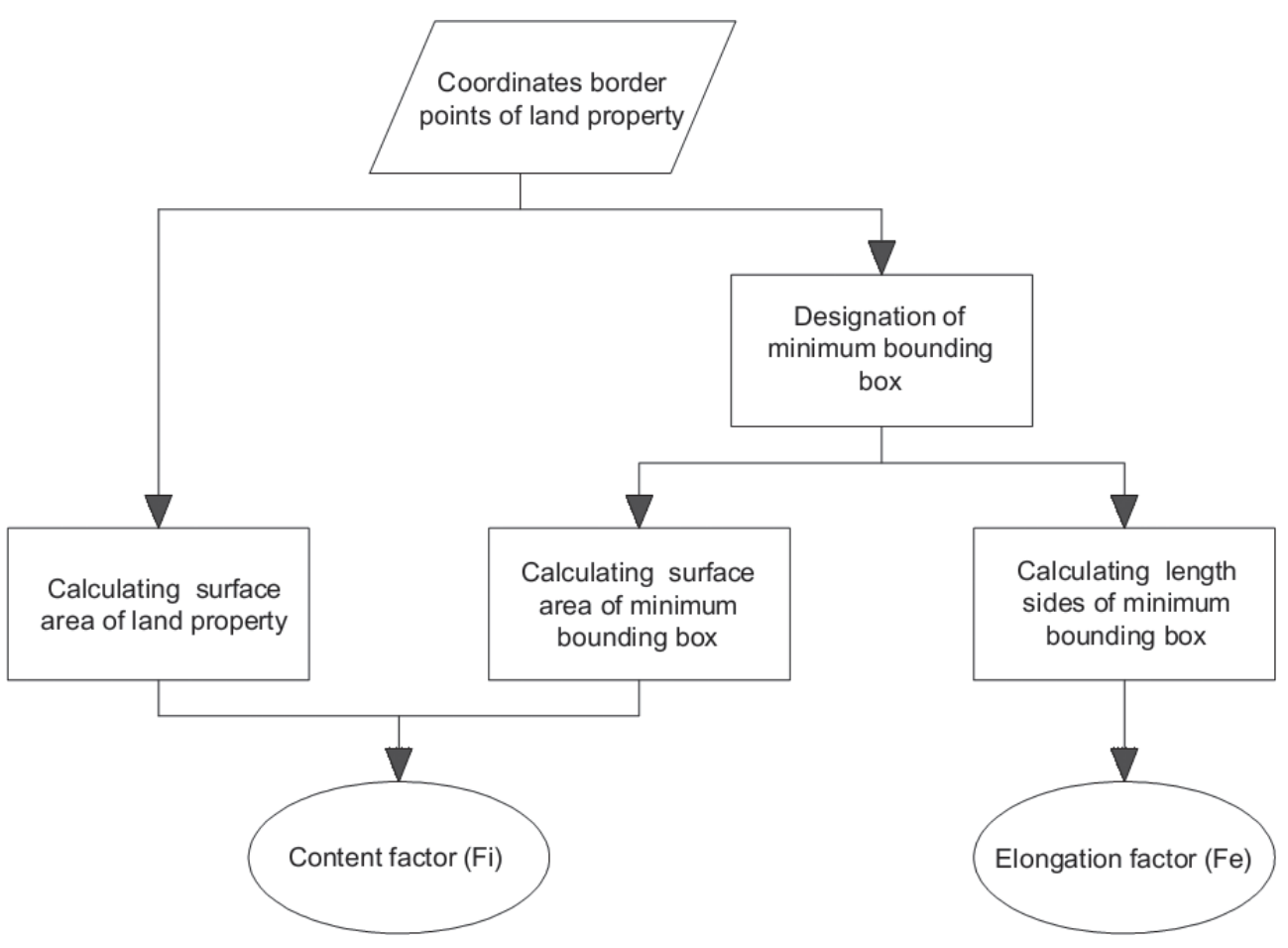

Fig. 1. Block diagram of algorithm

Both coefficients assume the values of the right-open range numbered from 0 to 1 . When the elongation factor is equal to one, it means that property land is contained in a square, where there is close to zero and it proves its significantly extended. Compactness factor equal to one while compactness means that property land fits perfectly into the bounding box, when it reaches a value close to zero consideration object is highly irregular in shape.

Using shown algorithm coefficients were calculated elongation and compactness factors for the following geometric configurations of test parcels (Fig. 2).

For the presented parcels (marked in blue), inscribed in minimum bounding box (red color), algorithm turned results condensed below (Tab. 1).

Table 1. Results for cadastral parcels

\begin{tabular}{|c|l|c|c|}
\hline $\begin{array}{c}\text { Designation } \\
\text { case }\end{array}$ & Description test parcels & $\begin{array}{c}\text { Elongation factor } \\
(F e)\end{array}$ & $\begin{array}{c}\text { Compactness factor } \\
(F i)\end{array}$ \\
\hline \hline a) & Triangle & 0.80 & 0.50 \\
\hline b) & Square & 1.00 & 1.00 \\
\hline c) & In shape similarrectangle & 0.44 & 0.86 \\
\hline d) & Irregular & 0.58 & 0.60 \\
\hline
\end{tabular}


a)

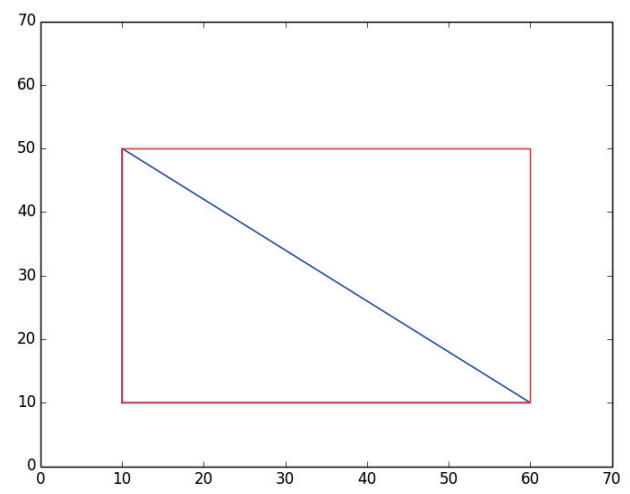

c)

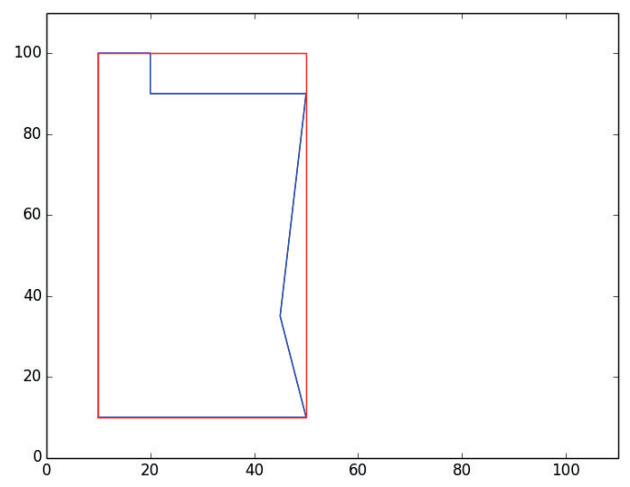

b)

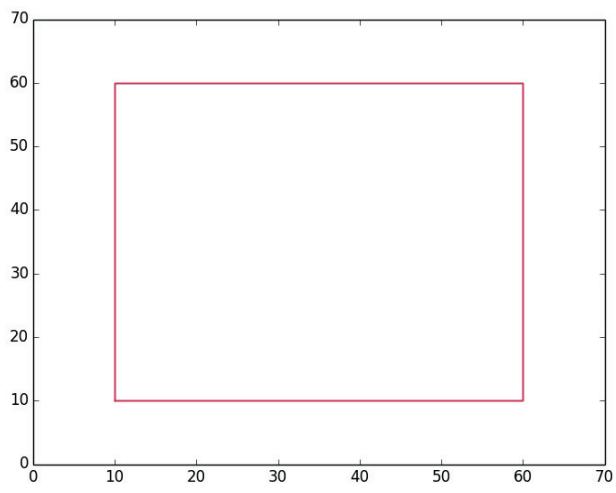

d)

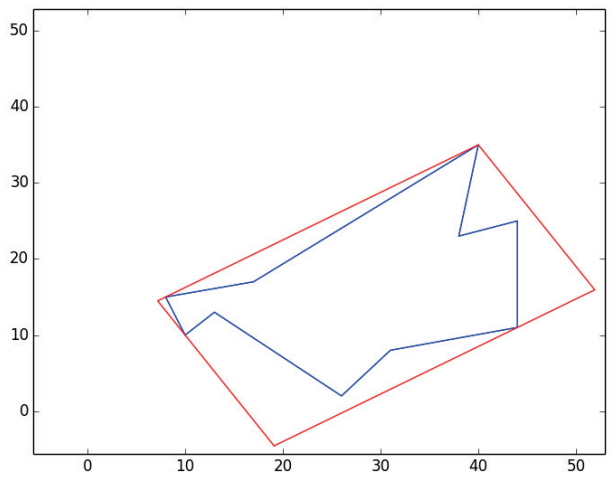

Fig. 2. Test parcels: a) shape of right triangular; b) shape of square; c) shape similar to rectangle; d) irregular shape.

Accomplished procedure autonomous evaluation geometric configuration of parcels faithfully reproduces compactness factor (Fi) regardless of the shape test object. More complex is interpretating the elongation factor $(\mathrm{Fe})$. As far as its geometric exemplification can be seen as a clear (i.e. factor of two sections), whereas values returned by algorithm can interfere in specific cases (e.g. with triangular parcels) of subjective human quantified rating - real estate appraiser. According to the adopted methodology $F e=0.80$, which corresponds with 4 in a 5-level scale interval. Visually, however, the shape of a triangle leads to a significantly lower evaluation than 2 (by discretionary assessment of the authors). It should therefore be in this place clearly emphasized dissection assessing geometry property land to assess elongation and uncorrelated with her assessment compactness. This means that a low value Fi does not affects the level factor $F e$. 


\section{Proposal Implementation of Algorithm to Process Property Valuation}

Subjectivism quantified assessment shape of land property, realized in form interval $(1,2,3, \ldots)$ or an adjective (unfavorable, average etc.), is particularly highlighted at valuations in litigious matters (e.g. opinions of expert witnesses), where frequent party to a dispute otherwise they perceive quality of shape plot land than was presented in valuation [3]. Inclusion in process estimating market value (or in future cadastral value) autonomous shape factor $(F s)$, designated as:

$$
F s=F e+F i
$$

eliminates the ambivalent nature of the assessment of real estate in context of its geometric configuration. The proposed parameterization also allows mass and unambiguously classification of all land property in particular market segment within a particular zone tax. The presentation will sample schema valuation taking into account the shape factor $(F s)$, collected information about eighteen undeveloped land properties, but are designed for residential single-family (Tab. 2).

Table 2. Representative sample of undeveloped land properties

\begin{tabular}{|c|c|c|c|c|c|c|c|}
\hline \multirow{3}{*}{ Id. } & \multirow{3}{*}{$\begin{array}{c}\text { Surface } \\
\text { area }\left[\mathrm{m}^{2}\right]\end{array}$} & \multicolumn{5}{|c|}{ Market characteristics } & \multirow{2}{*}{$\begin{array}{l}\text { Unit price } \\
\text { transaction } \\
{\left[\mathrm{PLN} / \mathrm{m}^{2}\right]}\end{array}$} \\
\hline & & $\begin{array}{l}\text { Location and } \\
\text { surroundings }\end{array}$ & $\begin{array}{c}\text { Shape } \\
\text { factor } \\
(F s)\end{array}$ & Media & Access & $\begin{array}{c}\text { Investment } \\
\text { opportunities }\end{array}$ & \\
\hline & & $a_{1}$ & $a_{2}$ & $a_{3}$ & $a_{4}$ & $a_{5}$ & $C_{T}$ \\
\hline 1 & 455 & 3 & 1.69 & 3 & 3 & 2 & 352.93 \\
\hline 2 & 350 & 2 & 1.73 & 3 & 3 & 3 & 318.06 \\
\hline 3 & 600 & 2 & 0.92 & 1 & 2 & 1 & 162.65 \\
\hline 4 & 721 & 2 & 1.00 & 2 & 2 & 2 & 184.83 \\
\hline 5 & 443 & 3 & 1.60 & 3 & 3 & 3 & 360.89 \\
\hline 6 & 743 & 3 & 1.83 & 2 & 1 & 3 & 337.62 \\
\hline 7 & 614 & 3 & 1.37 & 1 & 1 & 3 & 284.04 \\
\hline 8 & 704 & 3 & 1.78 & 1 & 3 & 3 & 356.61 \\
\hline 9 & 907 & 3 & 1.27 & 1 & 1 & 2 & 252.65 \\
\hline 10 & 715 & 3 & 1.00 & 3 & 3 & 1 & 266.23 \\
\hline 11 & 346 & 2 & 0.84 & 3 & 3 & 3 & 264.32 \\
\hline 12 & 350 & 2 & 1.15 & 3 & 3 & 3 & 263.58 \\
\hline 13 & 834 & 1 & 1.49 & 1 & 2 & 2 & 221.06 \\
\hline 14 & 507 & 3 & 1.86 & 3 & 3 & 3 & 406.07 \\
\hline 15 & 631 & 1 & 0.85 & 2 & 1 & 1 & 125.95 \\
\hline 16 & 500 & 3 & 1.70 & 3 & 3 & 3 & 406.24 \\
\hline 17 & 739 & 3 & 1.07 & 1 & 1 & 3 & 292.88 \\
\hline 18 & 533 & 3 & 1.14 & 3 & 3 & 3 & 366.80 \\
\hline
\end{tabular}


Shape factor determined in accordance with formula (3), based on coordinates of points breakdown parcels, embedded in local plane coordinate system. Gathered in Table 2 market observations have also been described including others, but quantified assessments attributes on a scale of 1 to 3. Due to size of representative sample, in the first weight fractions of market characteristics established by juxtaposing system of equations in general form:

$$
C_{T j}=c_{m}+a_{1 j} \cdot k_{1}+a_{2 j} \cdot k_{2}+a_{3 j} \cdot k_{3}+a_{4 j} \cdot k_{4}+a_{5 j} \cdot k_{5}
$$

where:

$$
\begin{gathered}
C_{T j}-\text { unit price transaction, } \\
c_{m}-\text { intercept model, } \\
k_{1}, k_{2^{\prime}} \ldots, k_{j}-\text { weight fractions of market characteristics, } \\
a_{1 j^{\prime}} a_{2 j^{\prime}} \ldots, a_{j}-\text { further market characteristics, wherein } a_{2 j}=F_{S j}
\end{gathered}
$$

In the present case it lists eighteen observations at parallel being six estimated parameters. To determine weight fractions can therefore be used Gauss-Markov model, which due to redundancy equation will have a solution in set of real numbers. Showing the equation (4) in matrix notation, system of equations takes following form:

$$
\left[\begin{array}{c}
C_{T 1} \\
C_{T 2} \\
\vdots \\
C_{T 18}
\end{array}\right]=\left[\begin{array}{ccccc}
1 & a_{11} & a_{21} & \cdots & a_{51} \\
1 & a_{12} & a_{22} & \cdots & a_{52} \\
\vdots & \vdots & \vdots & \ddots & \vdots \\
1 & a_{118} & a_{218} & \cdots & a_{518}
\end{array}\right]\left[\begin{array}{c}
c_{m} \\
k_{1} \\
k_{2} \\
\vdots \\
k_{5}
\end{array}\right]+\left[\begin{array}{c}
\delta_{T 1} \\
\delta_{T 2} \\
\vdots \\
\delta_{T 18}
\end{array}\right]
$$

A simplified form of above notation expressed following formula:

$$
\left[C_{T}\right]=[a][k]+\left[\delta_{T}\right]
$$

where:

$\left[C_{T}\right]$ - vector of unit transaction prices,

$[a]$ - rectangular matrix build of ones in first column and market characteristics in subsequent columns,

$[k]$ - vector of weight fractions of market characteristics,

$\left[\delta_{T}\right]$ - vector of random deviations model.

Solution of equations (6) according to method smallest sum squares, leads to following dependence [1]:

$$
[\hat{k}]=\left([a]^{T}[a]\right)^{-1}[a]^{T}\left[C_{T}\right]
$$


Respectively large sample property allowed for the establishment of independent weight factors adopted characteristics market, called $\beta$ weight, which also included the shape factor $\left(F s=a_{2}\right)$. This approach defines the influence of one exogenous variable (attribute real estate) on endogenous variable (transaction price) at parallel deprivation impact of others independent variables. Weight $\beta$ were realized based on following formula:

$$
\beta_{i}=\hat{k}_{i} \cdot \frac{\sigma\left(a_{i}\right)}{\sigma\left(C_{T}\right)}
$$

wherein $\sigma\left(a_{i}\right)$ is standard deviation of characteristics market, calculated as:

$$
\sigma\left(a_{i}\right)=\sqrt{\frac{\sum_{j=1}^{n}\left(a_{i j}-\bar{a}_{j}\right)^{2}}{n}}
$$

and is standard deviation of unit transaction prices, numerous as:

$$
\sigma\left(C_{T}\right)=\sqrt{\frac{\sum_{i=1}^{n}\left(C_{T j}-\bar{C}_{T}\right)^{2}}{n}}
$$

The purpose of unambiguous identification impact of shape factor $(F s)$ on unit transaction prices, weight fractions where processed normalization, by which the sum of standardized $\beta$ weight was $100 \%$. The results of the accounting processes are summarized in Table 3.

Table 3. Summary model estimates and autonomous $\beta$ weights

\begin{tabular}{|l|c|c|c|c|}
\hline \multicolumn{1}{|c|}{ Characteristic market } & Sign & Estimator & Weight $\beta[\%]$ & Normalized weight $\beta$ [\%] \\
\hline \hline Intercept model & $c_{m}$ & -78.14 & - & - \\
\hline Location and surroundings & $\hat{k}_{1}$ & 48.92 & 43 & 31 \\
\hline Shape factor $(F s)$ & $\hat{k}_{2}$ & 82.07 & 37 & 26 \\
\hline Media & $\hat{k}_{3}$ & 12.77 & 15 & 10 \\
\hline Access & $\hat{k}_{4}$ & 16.43 & 18 & 13 \\
\hline Investment opportunities & $\hat{k}_{5}$ & 28.71 & 28 & 20 \\
\hline
\end{tabular}

Based on the results listed above clarified high impact shape factor on unit prices. This is a consequence precision assigned elongation factor $(F e)$ and compactness factor $(F i)$ properties from a representative sample. There is no issue here also quantified assessment, which raises a risk assessment of relatively similar objects in extremely different scales. 
The model estimation weigh fraction of the characteristic market allows you to analyze the accuracy of structural parameters. After implementation to scheme (6) vector estimators $[\hat{k}]$, vector of random deviations model $\left[\hat{\delta}_{T}\right]$ expressed according to form [2]:

$$
\left[\hat{\delta}_{T}\right]=\left[C_{T}\right]-[a][\hat{k}]
$$

Variance-covariance matrix $\operatorname{cov}(\hat{k})$ estimated parameters expressed by the formula:

$$
\operatorname{cov}(\hat{k})=\sigma_{0}^{2} \cdot\left([a]^{T}[a]\right)^{-1}
$$

Wherein $\sigma_{0}^{2}$ is variance of random residues designated by exercising the following model:

$$
\hat{\sigma}_{0}^{2}=\frac{\left[\hat{\delta}_{T}\right]^{T}\left[\hat{\delta}_{T}\right]}{n-R[a]}
$$

where:

$n$ - number of observations (real estate) in a representative sample,

$R[a]$ - government matrix $[a]$.

Square roots diagonal elements of a matrix variance-covariance, represent standard deviation model estimators. They are summarized in Table 4.

Table 4. List of model estimates and their standard deviations

\begin{tabular}{||l|c|c|c||}
\hline \multicolumn{1}{|c|}{ Market characteristic } & Sign & Estimator & $\begin{array}{c}\text { Standard } \\
\text { deviation }\end{array}$ \\
\hline Intercept model & $\mathrm{c}_{\mathrm{m}}$ & -78.14 & 24.79 \\
\hline Location and surroundings & $\hat{k}_{1}$ & 48.92 & 8.37 \\
\hline Shape factor $(F s)$ & $\hat{k}_{2}$ & 82.07 & 17.49 \\
\hline Media & $\hat{k}_{3}$ & 12.77 & 8.20 \\
\hline Access & $\hat{k}_{4}$ & 16.43 & 8.58 \\
\hline Investment opportunities & $\hat{k}_{5}$ & 28.71 & 8.10 \\
\hline
\end{tabular}

Based on the analysis of the results listed in Table 4, it is considered the statistical significance of all analyzed characteristics market. Standard deviations for absolute values do not exceed estimates model. Thus, they may form the basis for estimating market value $(W)$ property land, according to following scheme:

$$
W=[\bar{a}][\hat{k}]
$$


wherein vector attributes [ $[\hat{a}]$ for a representative subject valuation takes values:

$$
[\bar{a}]=\left[\begin{array}{llllll}
1 & 3 & 1.53 & 3 & 3 & 3
\end{array}\right] .
$$

Taking into account that vector and structural parameters model, unit market value of representative property was set at $W=367.93 \mathrm{PLN} / \mathrm{m}^{2}$. The variance of estimated value property should be determined taking into account variance-covariance matrix (12), so by implementing the following formula:

$$
\sigma^{2}(W)=[\bar{a}] \cdot \operatorname{cov} \hat{k} \cdot[\bar{a}]^{T}
$$

In the case at variance estimated value is $\sigma^{2}(W)=3557.9169$, reflecting standard deviation which is equal to $\sigma(W)=59.65 \mathrm{PLN} / \mathrm{m}^{2}$.

\section{Conclusions}

Proposed in pages of this paper algorithm autonomous assessment geometric configuration of property land faithfully reproduces compactness factor (Fi) calculated as ratio surface area of cadastral parcel to area of minimum bounding box. The determined value this parameter is significant for plots land of any run border. More complex is the interpretation of the elongation factor $(F e)$, because returned algorithm values can interfere in specific cases (e.g. with triangular land plots) with subjective, quantified rating by real estate appraiser.

In the context of all characteristic market stratification elongation and compactness factor may lead to conclusion for their statistical insignificance. Therefore, it is proposed that a summary of indicators and include them as a measure real to process estimation weight fractions of characteristics markets. It is also proposed to influence pricing factors set in each case based on $\beta$ weight. Such an approach clarifies the uniformity of the features of the adopted market. Estimation model parameters by Gauss-Markov model allows complete analysis variance and answer to the question of statistical significance structural parameters model by estimating stochastic parameters. Positive verification vector estimators to estimate market or cadastral value based on a model that takes into account both parameterized assessment shape, by copyright concept, and quantified evaluation others market characteristics.

In repetition emphasizes, that proposed methodology for assessing shape of property land almost completely eliminates the human factor as discretionary, subjective evaluation by real estate appraisal. His role because it is imported to obtain plane coordinates border points, set in local or national orthogonal system. Therefore, it is assumed, that shape factor $(F s)$ is an autonomous measure of geometrical configuration property land or parcels. 


\section{References}

[1] Czaja J.: Metody szacowania wartości rynkowej i katastralnej nieruchomości. KOMP-SYSTEM, Kraków 2001.

[2] Czaja J., Parzych P.: Zaawansowane modele statystyczne wyceny nieruchomości zurbanizowanych. Studia i Materiały Towarzystwa Naukowego Nieruchomości, vol. 16, no. 3, 2008, pp. 7-16.

[3] Egner W.: Współczynnik kształtu. [on-line:] http://www.egner.pl [access: 01.10.2015].

[4] Krzyżek R.: Obliczanie pola powierzchni z wykorzystaniem metod: analitycznej, graficznej, analityczno-graficznej, komputerowej $i$ pozyskiwania danych w czasie rzeczywistym. [on-line:] http://home.agh.edu.pl/ rkrzyzek [access: 01.10.2015].

[5] KSWS: Wycena nieruchomości rolnych (projekt). Polska Federacja Stowarzyszeń Rzeczoznawców Majątkowych, Warszawa 2014.

[6] Mielewczyk S.: Wymierna ocena efektu scalenia gruntów gospodarstw rolnych spowodowanego poprawa ksztattu pól użytku zielonego. Acta Scientiarum Polonorum, Geodesia et Descriptio Terrarum, no. 11 (3), 2012, pp. 5-16.

[7] Podciborski T., Kil J.: Ład przestrzenny obszarów peryferyjnych w aspekcie podziałów nieruchomości niezurbanizowanych. Barometr Regionalny, no. 3 (25), 2011, pp. 79-84.

[8] Ustawa z dnia 21 sierpnia 1997 r. o gospodarce nieruchomościami. Dz.U. 2014, poz. 518 z późniejszymi zmianami [Journal of Laws 2014, item 518 with amendments]. 